\title{
Leucocyte Blood Picture in Ill Newborn Babies
}

\author{
MARIETTA XANTHOU \\ From the Neonatal Research Unit, Institute of Child Health, Hammersmith Hospital, London
}

\begin{abstract}
Xanthou, M. (1972). Archives of Disease in Childhood, 47, 741. Leucocyte blood picture in ill newborn babies. Serial blood leucocyte counts were made on 35 ill preterm and term babies during the first 28 days of life.

Ill babies with no clinical or bacteriological evidence of infection showed no changes in the blood leucocytes during the neonatal period when compared with normal babies.

The changes in the blood leucocytes in babies with proven or suspected bacterial infection were an increase in the absolute values of polymorphonuclear neutrophils, an increase in the absolute values of immature neutrophils, a significant fall in polymorphonuclear neutrophils (below $1000 / \mathrm{mm}^{3}$ ) and in eosinophils (down to 0 ) in very ill babies, and toxic granulation of neutrophils.
\end{abstract}

Blood leucocyte counts in newborn babies have generally been considered to be so variable and unpredictable as to be of little value for clinical purposes. Leucocyte studies in ill babies have therefore been thought to be unnecessary, so that few authors have dealt with this subject (Hofmann and Welcker, 1925; Rogatz, 1930; Muhl, 1949; Klees, Schlagetter, and Wokkittel, 1958; Straková, 1964).

Serial measurements of the leucocytes in the blood of healthy term and preterm newborns with attention given to the absolute number of individual cell-types have shown, however, that changes in the leucocyte count in the first days and weeks of life follow a constant pattern and that normal ranges can be established (Xanthou, 1970). The purpose of the present study was to determine if there were any meaningful changes in the blood leucocytes in association with illness in preterm and term babies in the neonatal period.

\section{Materials}

Thirty-five ill babies were studied, consisting of the following groups.

A. 11 preterm infants in whom a diagnosis of bacterial illness was not entertained: the majority had respiratory distress.

B. 11 infants in whom a diagnosis of bacterial infection was considered likely on clinical grounds; 3 were born at term, the remainder were preterm.

In these infants, and in those of group A, 4 or 5

Received 21 February 1972. blood counts were done on each during the course of the illness during the first month of life.

C. 13 infants, all with birthweights below $2500 \mathrm{~g}$, and born before the 38th week, in whom bacterial infection was also considered likely. In all these, serial leucocyte counts were already being done when they became ill, as part of a study to determine the neonatal blood leucocyte pattern (Xanthou, 1970). The first blood sample had been obtained within 30 minutes of birth, and thereafter samples were collected daily until the 20th to 28th day.

Infants in groups $A$ and $B$ were treated with antibiotics.

Criteria for diagnosis of bacterial infection. The difficulty in establishing a diagnosis of infection during the neonatal period is well known. Clinical grounds for placing the 25 infants in groups B and C included a history of a long interval between membrane rupture and birth; abnormal behaviour such as recurrent apnoea, failure to suck well, and lethargy appearing in previously normal infants; the appearance of crepitations in the lungs where previously there had been none, and/or a purulent tracheal aspirate in ventilated infants; unusual jaundice; enlarged kidneys on abdominal palpation; or sustained fever. The final diagnosis of bacterial infection, however, rested on laboratory evidence. It might be considered proven if, for example, positive cultures were obtained from CSF or blood stream; if in urine bacterial counts of $10^{5}$ organisms were obtained on culture of a clean-catch specimen with white cell counts of more than $10 / \mathrm{cm}^{3}$; if there was a sharp rise in serum immunoglobulin levels, particularly IgM above accepted standards for the age; if there were histological evidence from necropsy material; or if there were radiological grounds combined with the clinical findings. 
Heavy bacterial colonization at a site such as the throat was not on its own regarded as satisfactory evidence.

\section{Methods}

Total white cell counts were made on a Coulter electronic counter which has an instrumental error of up to $2 \%$. The total error of the method, however. including heel-prick collection, pipetting, and diluting has been estimated as up to $8 \%$ (Richar and Breakell, 1959). The films were stained by the combined May-Grünwald-Giemsa method and cover-slips were used. For the differential examination, 2 sets of 100 cells were counted with a repeat examination of a further 200 if the difference between the original counts in respect of any cell type was greater than $10 \%$.

The blast cells were not differentiated into myeloblast, lymphoblast, or monoblast. No attempt was made to count nuclear lobules in polymorphonuclear neutrophils; recent studies with $\mathrm{H}_{3}$-thymidine suggest that the number of nuclear lobules is not correlated with the maturation of the cells (Fliedner et al., 1964).

\section{Results}

Final diagnosis of bacterial infection. There

Infants with Prove

\begin{tabular}{|c|c|c|c|c|c|}
\hline $\begin{array}{l}\text { Case } \\
\text { No. }\end{array}$ & $\begin{array}{c}\text { Gestational } \\
\text { Age } \\
\text { (wk) }\end{array}$ & $\begin{array}{c}\text { Birthweight } \\
\text { (g) }\end{array}$ & Sex & $\begin{array}{l}\text { Age } \\
\text { at } \\
\text { Onset } \\
\text { (dy) }\end{array}$ & Nature of Infection \\
\hline $\begin{array}{c}1 \\
2 \dagger \\
3 \dagger \\
4 \dagger \\
5 \\
6 \dagger \\
7 \\
8 \\
9 \\
10 \\
11 t\end{array}$ & $\begin{array}{l}29 \\
38 \\
39 \\
28 \\
38 \\
30 \\
34 \\
33 \\
33 \\
33 \\
30\end{array}$ & $\begin{array}{l}1960 \\
3560 \\
3640 \\
1010 \\
1920 \\
1230 \\
2060 \\
1380 \\
2000 \\
1900 \\
1520\end{array}$ & $\begin{array}{l}M \\
M \\
M \\
F \\
M \\
M \\
M \\
F \\
M \\
M \\
F\end{array}$ & $\begin{array}{r}8 \\
22 \\
3 \\
7 \\
5 \\
3 \\
8 \\
5 \\
2 \\
10 \\
2\end{array}$ & $\begin{array}{l}\text { Peritonitis due to perforation of caecum } \\
\text { Septicaemia } \\
\text { Septicaemia; pneumonia } \\
\text { Peritonitis due to perforation of ascending colon } \\
\text { Septicaemia; pneumonia } \\
\text { Pneumonia } \\
\text { Pneumonia } \\
\text { Pneumonia } \\
\text { Pneumonia } \\
\text { Septicaemia; pneumonia } \\
\text { Pneumonia }\end{array}$ \\
\hline
\end{tabular}

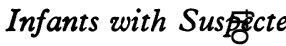

\begin{tabular}{|c|c|c|c|c|c|}
\hline Case No. & $\begin{array}{l}\text { Gestational } \\
\text { Age } \\
\text { (wk) }\end{array}$ & $\begin{array}{l}\text { Birthweight } \\
(\mathrm{g})\end{array}$ & Sex & $\begin{array}{l}\text { Age at } \\
\text { Onset } \\
\text { (dy) }\end{array}$ & Grounds for Suspicion of Infection \\
\hline 12 & 30 & 1300 & $\mathbf{F}$ & 3 & $\begin{array}{l}\text { Offensive liquor; IgM } 7 \mathrm{mg} / 100 \mathrm{ml} \text { (1st day), } 22 \mathrm{mg} / 100 \mathrm{ml} / \mathrm{C} \\
\text { day); slight respiratory distress, radio-opacity } \mathrm{RMZ} \text {, later clegri }\end{array}$ \\
\hline $\begin{array}{l}13 \\
14\end{array}$ & $\begin{array}{l}26 \\
36\end{array}$ & $\begin{array}{r}800 \\
2580\end{array}$ & $\begin{array}{l}\mathbf{M} \\
\mathbf{M}\end{array}$ & $\begin{array}{l}6 \\
8\end{array}$ & $\begin{array}{l}\text { Membranes ruptured } 7 \text { dy before birth; recurrent apnoea } \\
\text { Membranes ruptured } 72 \mathrm{hr} \text { before birth; IgM } 22 \mathrm{mg} / 100 \mathrm{0} \\
\text { (2nd day) }\end{array}$ \\
\hline 15 & 26 & 920 & $\mathbf{F}$ & 4 & $\begin{array}{l}\text { Membranes ruptured } 55 \mathrm{hr} \text { before birth; IgM } 14 \mathrm{mg} / 100 \mathrm{~m}+(3 \mathrm{r} \\
\text { day), } 53 \mathrm{mg} / 100 \mathrm{ml} \text { (9th day); necrosis of pinna }\end{array}$ \\
\hline 16 & 30 & 820 & $\mathbf{F}$ & 5 & $\begin{array}{l}\text { Membranes ruptured } 10 \text { dy before delivery; recurrent apnoea; } \\
10 \mathrm{mg} / 100 \mathrm{ml} \text { (2nd day), } 32 \mathrm{mg} / 100 \mathrm{ml} \text { (9th day) }\end{array}$ \\
\hline $17 t$ & 33 & 1700 & $\mathbf{M}$ & 1 & $\begin{array}{l}\text { Recurrent apnoea; IgM } 21 \mathrm{mg} / 100 \mathrm{ml} \text { (1st day); klebsiella cuptur } \\
\text { from throat swab within few hours of birth; no necropsy; moth } \\
\text { postpartum pyrexia }\end{array}$ \\
\hline $\begin{array}{l}18 \\
19\end{array}$ & $\begin{array}{l}30 \\
35\end{array}$ & $\begin{array}{l}1510 \\
2780\end{array}$ & $\begin{array}{l}\mathbf{M} \\
\mathbf{M}\end{array}$ & $\begin{array}{l}6 \\
2\end{array}$ & $\begin{array}{l}\text { Recurrent apnoea; enlarged kidneys on palpation, later normf } \\
\text { Respiratory distress, radio-opacity RLZ, later clearing; } \\
10 \mathrm{mg} / 100 \mathrm{ml} \text { (1st day), } 22 \mathrm{mg} / 100 \mathrm{ml} \text { (7th day) }\end{array}$ \\
\hline $\begin{array}{l}20 \dagger \\
21\end{array}$ & $\begin{array}{l}25 \\
28\end{array}$ & $\begin{array}{r}760 \\
1100\end{array}$ & $\begin{array}{l}F \\
F\end{array}$ & $\begin{array}{l}1 \\
5\end{array}$ & $\begin{array}{l}\text { Recurrent apnoea; necropsy: focal early pneumonia } \\
\text { Recurrent apnoea; IgM } 46 \mathrm{mg} / 100 \mathrm{ml} \text { (10th day); smalthar } \\
\text { radio-opacity RLZ, later clearing }\end{array}$ \\
\hline $\begin{array}{l}22 \\
23\end{array}$ & $\begin{array}{l}26 \\
30\end{array}$ & $\begin{array}{r}920 \\
1380\end{array}$ & $\begin{array}{l}\mathbf{M} \\
\mathbf{M}\end{array}$ & $\begin{array}{l}8 \\
6\end{array}$ & $\begin{array}{l}\text { Recurrent apnoea; crepitations at lung bases } \\
\text { Maternal pyrexia pre- and postpartum; IgM } 54 \mathrm{mg} / 100 \mathrm{~m} / \mathrm{q} 2 \mathrm{r} \\
\text { day); infant febrile } 9 \text { th day }\end{array}$ \\
\hline 24 & 36 & 2260 & $\mathbf{M}$ & 11 & $\begin{array}{l}\text { Lethargy; crepitations over LLL; IgM } 2 \mathrm{mg} / 100 \mathrm{ml} \text { (1st cedf } \\
35 \mathrm{mg} / 100 \mathrm{ml} \text { (14th day) }\end{array}$ \\
\hline \multicolumn{6}{|c|}{ 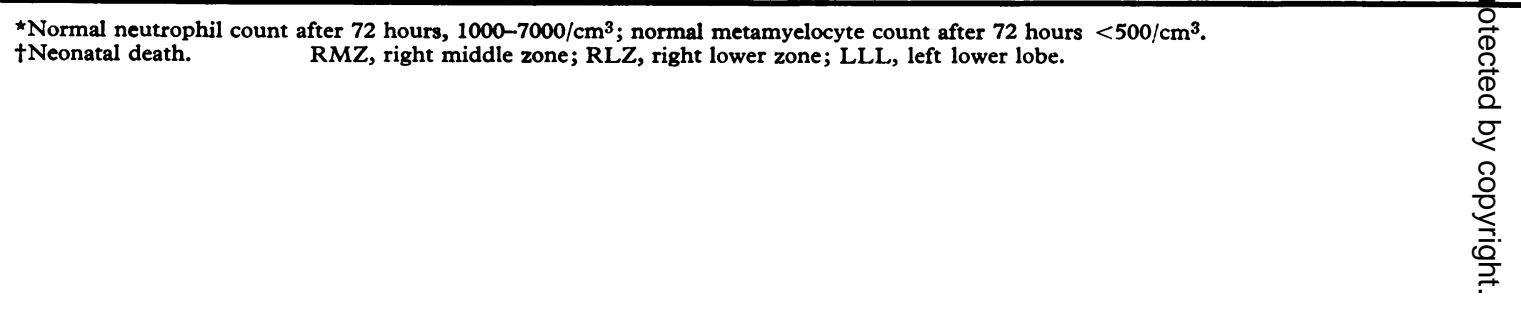 } \\
\hline
\end{tabular}


was no later evidence to suggest that any of the ill preterm infants of group $A$ had bacterial infection. Among the 24 infants in groups $B$ and $C$, however, all considered as potentially infected on clinical grounds, a final diagnosis of infection using the laboratory criteria mentioned above was substantiated in 11 only (see Table I), of whom 7 were in group $B$ and 4 in group $C$. In the remaining 13 infants, bacterial infection was considered possible, but not proven; it might have been modified by antibiotic therapy (see Table II).
Changes of neutrophils with illness. The neutrophil leucocytes of the ill, but non-infected preterm infants in group A showed no differences in number or appearance when compared with the normal series. They will not be considered further.

All infants in groups B and C, whether their bacterial infection was proven or merely suspected, showed both qualitative and quantitative changes.

Quantitative changes. There was usually a significant and a considerable increase in the absolute values of polymorphonuclear neutrophils.

\begin{tabular}{|c|c|c|c|c|c|c|}
\hline \multirow{2}{*}{$\begin{array}{l}\text { Infecting } \\
\text { Organism }\end{array}$} & \multicolumn{2}{|c|}{$\begin{array}{l}\text { Polymorphonuclear } \\
\text { Neutrophils } / \mathrm{mm}^{3 \star}\end{array}$} & \multicolumn{2}{|c|}{$\begin{array}{c}\text { Total } \\
\text { Metamyelocytes } / \mathrm{mm}^{3 \star}\end{array}$} & \multirow{2}{*}{$\begin{array}{c}\text { Other } \\
\text { Immature } \\
\text { Forms }\end{array}$} & \multirow{2}{*}{$\begin{array}{c}\text { Toxic } \\
\begin{array}{c}\text { Granulation } \\
\text { of }\end{array} \\
\text { Neutrophils }\end{array}$} \\
\hline & Maximum & Minimum & Maximum & Minimum & & \\
\hline $\begin{array}{l}\text { Esch. coli } \\
\text { Staph. albus } \\
\text { Strep. faecalis } \\
\text { (Not isolated) } \\
\text { Esch. coli } \\
\text { (Not isolated) } \\
\text { Esch. coli } \\
\text { Klebsiella } \\
\text { Staph. albus } \\
\text { Staph. albus } \\
\text { (Not isolated) }\end{array}$ & $\begin{array}{r}15500 \\
11700 \\
3750 \\
8200 \\
8000 \\
2000 \\
7000 \\
4500 \\
7600 \\
7700 \\
6700\end{array}$ & $\begin{array}{r}3600 \\
5000 \\
3500 \\
1000 \\
2200 \\
450 \\
2500 \\
1800 \\
1400 \\
2800 \\
100\end{array}$ & $\begin{array}{r}3300 \\
600 \\
6200 \\
600 \\
1000 \\
500 \\
600 \\
800 \\
700 \\
2000 \\
1500\end{array}$ & $\begin{array}{r}750 \\
100 \\
5250 \\
150 \\
200 \\
500 \\
150 \\
400 \\
250 \\
800 \\
300\end{array}$ & $\begin{array}{c}++ \\
++ \\
+++ \\
+ \\
++ \\
+ \\
++ \\
++ \\
+ \\
+++ \\
+++\end{array}$ & $\begin{array}{c}+++ \\
++ \\
+ \\
+++ \\
+++ \\
+++ \\
+ \\
+++ \\
+++ \\
+ \\
\end{array}$ \\
\hline
\end{tabular}

acterial Infection

\begin{tabular}{|c|c|c|c|c|c|}
\hline \multicolumn{2}{|c|}{ Total Polymorphonuclear Neutrophils/mm ${ }^{3 \star}$} & \multicolumn{2}{|c|}{ Total Metamyelocytes $/ \mathrm{mm}^{3 \star}$} & \multirow{2}{*}{$\begin{array}{l}\text { Other } \\
\text { Immature } \\
\text { Forms }\end{array}$} & \multirow{2}{*}{$\begin{array}{c}\text { Toxic } \\
\text { Granulation } \\
\text { of Neutrophils }\end{array}$} \\
\hline Maximum & Minimum & Maximum & Minimum & & \\
\hline 17500 & 6000 & 3300 & 50 & ++ & +++ \\
\hline $\begin{array}{l}8300 \\
5200\end{array}$ & $\begin{array}{l}4000 \\
3500\end{array}$ & $\begin{array}{r}1200 \\
500\end{array}$ & $\begin{array}{l}300 \\
150\end{array}$ & $\stackrel{+}{-}$ & $\begin{array}{c}++ \\
++\end{array}$ \\
\hline 7500 & 2000 & 1900 & 300 & ++ & - \\
\hline 8700 & 4500 & 1400 & 1000 & ++ & - \\
\hline 17000 & 12000 & 2800 & 1500 & ++ & - \\
\hline $\begin{array}{l}4500 \\
6800\end{array}$ & $\begin{array}{l}1800 \\
3800\end{array}$ & $\begin{array}{l}400 \\
750\end{array}$ & $\begin{array}{l}100 \\
400\end{array}$ & $\overline{t+}$ & $\square$ \\
\hline $\begin{array}{r}3600 \\
600\end{array}$ & $\overline{440}$ & 8000 & $\bar{Z}$ & ++ & $\bar{Z}$ \\
\hline $\begin{array}{l}10500 \\
17500\end{array}$ & $\begin{array}{r}3250 \\
10080\end{array}$ & $\begin{array}{r}1200 \\
500\end{array}$ & $\begin{array}{l}300 \\
168\end{array}$ & $\begin{array}{l}++ \\
++\end{array}$ & $\begin{array}{c}+++ \\
++\end{array}$ \\
\hline 9000 & 3000 & 100 & 50 & - & $\longrightarrow$ \\
\hline
\end{tabular}


While in healthy term and preterm babies the absolute values of polymorphonuclear neutrophils after the first 3 days of life never exceeded 7000/ $\mathrm{mm}^{3}$, in these ill infants they were usually found in numbers exceeding this value, sometimes reaching as high as $17,500 / \mathrm{mm}^{3}$ (see Table II).

It was a noticeable feature of the white cell counts in the healthy premature and term babies that the polymorphonuclear neutrophil count did not vary from day to day by more than the experimental error of the method (Xanthou, 1970). Significant daily variations of these cells were, however, found in some of the babies suffering from infection.

In some babies with undoubted and very severe infective illness, the polymorphonuclear neutrophil count dropped to low levels, sometimes below $1000 / \mathrm{mm}^{3}$, and where there was a previous count this drop was sometimes found to be very abrupt. Preceding or accompanying the rise or fall in neutrophils though, there was nearly always a significant rise in metamyelocytes and sometimes in more immature forms (myelocytes, promyelocytes, blast cells)-metamyelocytes sometimes exceeding $1000 / \mathrm{mm}^{3}$. When the polymorphonuclear count was normal or low at the onset of illness and the baby improved, there was a rise in neutrophils usually within 24 hours, but if the baby deteriorated the neutrophil count remained low and the numbers of other immature cells also dropped before death (see Fig. 1 and 2).

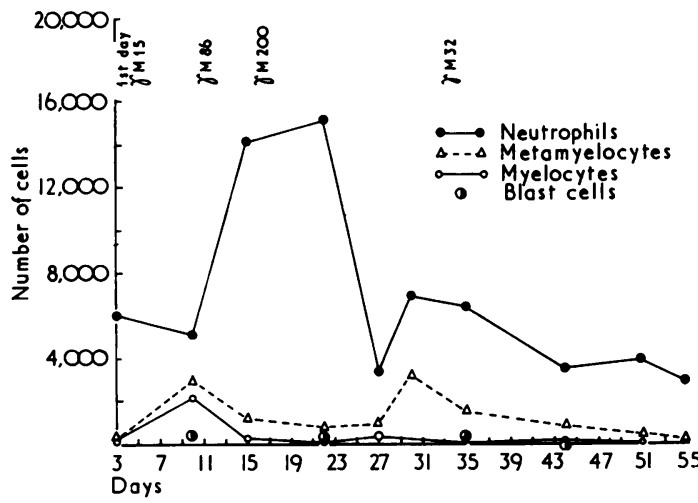

FIG. 1.-This baby (Case 1, Table I) of 29 weeks' gestation developed recurrent apnoea and signs of intestinal obstruction on the 8th day of life. White cell count at this time showed a marked increase of immature cells without a rise in polymorphonuclear neutrophils. At operation the following day a perforated gangrenous caecum was found. Postoperatively the polymorphonuclear neutrophil count rose from 6000 to $14,000 / \mathrm{mm}^{3}$, and the serum IgM which was $15 \mathrm{mg} / 100 \mathrm{ml}$ on the first day of life had risen to $200 \mathrm{mg} / 100 \mathrm{ml}$. The baby survived and his white cell count gradually returned to normal.

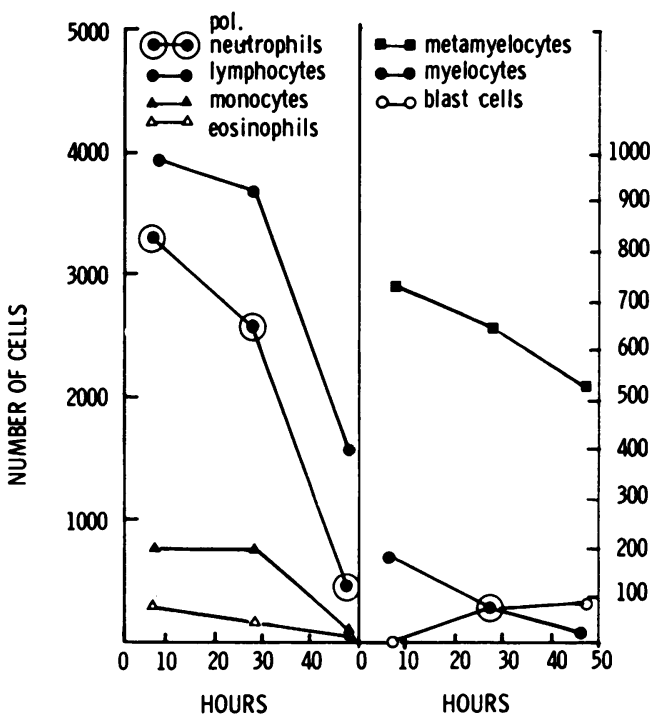

Fig. 2.-This baby (Case 11, Table I) of 30 weeks' gestation had respiratory distress and respiratory infection. Artificial ventilation was required. He died at 56 hours of age. There was an abrupt fall of polymorphonuclears and a gradual fall of the more immature neutrophils before death.

Qualitative changes. An increase in the ratio of band forms to polymorphonuclear neutrophils was found in all cases, and in some the proportion of band forms was as high as $90 \%$.

With severe infection, toxic granulation of the neutrophils was almost invariably present, a change never seen in healthy newborn babies (see Fig. 3).

Whereas in severe proven infections most of these quantitative and qualitative changes in the neutrophil series were to be found, in less severe but proven infections fewer changes were found, and in possible infections only one or two.

Changes of eosinophils with illness. No definite changes were found in the blood eosinophils of term or preterm babies in group $A$. With overwhelming infection the absolute numbers of eosinophils tended to decrease and finally to fall to zero shortly before death.

Changes of basophils with illness. The basophils tended to follow the fluctuations of the blood eosinophils.

Changes of lymphocytes with illness. No changes were found in the blood lymphocytes of term or preterm babies in group A. A small drop 


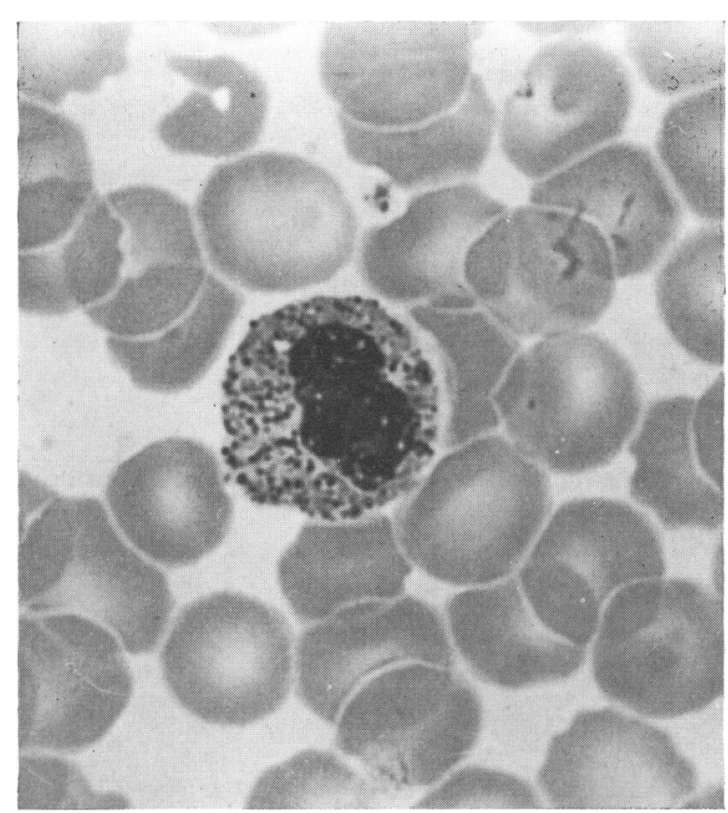

FIG. 3.-Immature neutrophil with marked toxic granulation (from Case 8, Table I). ( $\times$ 1600.)

in the absolute numbers of lymphocytes was found only in overwhelming infection.

Changes of monocytes with illness. No changes in the monocytes were seen in any of the 35 babies studied.

\section{Discussion}

We have observed obvious changes in the peripheral blood of the various white cell types, and particularly the neutrophils, during both proven and suspected infective illness. There is an increase in the absolute number of mature and immature neutrophils; this is presumably due to increased bone marrow activity, and possibly also to the displacement of granulocytes from the marginal layers of vessels. The neutrophil response to illness in the neonatal period has been noticed by a few authors in the past (Muhl, 1949; Klees et al., 1958; Straková, 1964); these studies are seldom referred to in the literature.

During the first 3 days of life, the number of neutrophils normally falls (Xanthou, 1970), so that their value gives little guidance in the diagnosis of infection unless the count falls very low. However, repeated blood counts after the 12th hour of life are useful, as in the presence of infection there may be a rise instead of the expected fall.

After the first 72 hours of life values of polymor- phonuclear neutrophils exceeding $7000 / \mathrm{mm}^{3}$ or significant daily differences in the counts were seen during proven and suspected infective illness, and this proved to be a very important diagnostic aid. A further diagnostic clue was the persistence of immature neutrophils in equal or raised numbers to those encountered normally in the first 3 days.

Of particular interest is the sometimes abrupt disappearance of the polymorphonuclear neutrophils from the blood in overwhelming infections. However, this is not altogether surprising in view of the short half-life of only 6 to 7 hours, due to the massive removal of injured cells, probably by the lungs (Boggs, 1967).

Another change is the decrease in the absolute values of eosinophils during overwhelming infection. This has been noticed in the past (Bach and Srithavat, 1960; Gaubert, Claverie, and Gaubert, 1960; Lorenz, 1960). Naiden and Ross (1954) believe this eosinopenia to be due to the hyperadrenalism found during severe infection.

The most important finding from this study has been (1) that there were no definite changes in white cell counts in ill babies in whom there was no evidence of bacterial infection, and (2) that there were marked changes, quantitative and/or qualitative in the neutrophils of both term and preterm babies suffering from either proven or suspected infective illness. However, since these changes were found to be present in both definitely infected and possibly infected infants we cannot be certain that such quantitative and qualitative changes are specific for infective illness. None the less, no baby thought to be suffering from infective illness was found to have a normal leucocyte count.

As can clearly be seen from the results of the present study the total white cell count is of only limited value in the diagnosis of illness during the neonatal period, and the differential count is required to determine the absolute values of the various cell types and the immature cells. In addition, inspection of the white cells is very important for the detection of band forms and toxic granulation.

I wish to thank Professor J. P. M. Tizard, Dr. Pamela Davies, and Professor J. V. Dacie, F.R.S., for their advice in connexion with this study, and the Sir William Coxen Trust Fund for laboratory facilities.

\section{REFERENCES}

Bach, H. G., and Srithavat, K. (1960). Zum Verhalten der Gesamteosinophilen im peripheren Blut in den ersten Lebenstagen. Zeitschrift für Geburtshilfe und Gynäkologie, 154, 151.

Boggs, D. R. (1967). The kinetics of neutrophilic leukocytes in health and in disease. Seminars in Hematology, 4, 359. 
Fliedner, T. M., Cronkite, E. P., Killmann, S. A., and Bond, V. P. (1964). Granulocytopoiesis. II. Emergence and pattern of labeling of neutrophilic granulocytes in humans. Blood, 24, 683.

Gaubert, J., Claverie, P., and Gaubert, J. (1960). Intérêt de l'éosinophilie sanguine chez le nourrisson et l'enfant. Presse Médicale, 68, 265.

Hofmann, A., and Welcker, A. (1925). Ueber die Bedeutung der Linksverschiebung im Blutbilde für Diagnose und Prognose. I. Das Blutbild des gesunden Säuglings. Archiv für Kinderheilkunde, 76, 1.

Klees, E., Schlagetter, K., and Wokkittel, E. (1958). Die Bedeutung des Neugeborenenblutbildes in der geburtshilflichen und pädiatrischen Praxis. Zeitschrift für Geburtshilfe und Gynäkologie, 151, 73.

Lorenz, K. (1960). Das Verhalten der Eosinophilen bei akuten Säuglingserkrankungen. Zeitschrift für Kinderheilkunde, 84, 154.

Muhl, G. (1949). On prophylactic and early treatment of infections in newborn infants, especially the premature. Acta Paediatrica, 37, 221.
Naiden, E., and Ross, S. (1954). The total circulating eosinophil count under environmental and stress stimuli. fournal of Pediatrics, 44, 145.

Richar, W. J., and Breakell, E. S. (1959). Evaluation of an electronic particle counter for the counting of white blood cells. American fournal of Clinical Pathology, 31, 384.

Rogatz, J. L. (1930). The Schilling blood count in the prognosis of acute infections in infancy and in childhood. American Fournal of Diseases of Children, 40, 70.

Straková, M. (1964). The white blood count in newborns. (Czech.) Acta Universitatis Carolinae, 10, 261.

Xanthou, M. (1970). Leucocyte blood picture in healthy full-term and premature babies during neonatal period. Archives $o$ Disease in Childhood, 45, 242.

Correspondence to Dr. M. Xanthou, 9 Meandrou Street, Athens 612, Greece. 